\title{
Castor bean allergy in the upholstery department of a furniture factory
}

\author{
M D TOPPING, ${ }^{1}$ F H TYRER, ${ }^{2}$ AND R K LOWING ${ }^{1}$ \\ From the Occupational Medicine and Hygiene Laboratories, ${ }^{1}$ London, and the Employment Medical \\ Advisory Service, ${ }^{2}$ Bristol; Health and Safety Executive, UK
}

ABSTRACT In this study, undertaken to identify the cause of allergy in several upholstery workers in a furniture factory, the workers were handling several different materials, including glue, silicone spray, upholstery fabrics, and felt. Radio-allergo-sorbent test (RAST) assays showed that sera from sensitised workers contained specific IgE towards the felt; however, further investigations using RAST showed that the allergen was not the felt itself but a contaminant of the felt. The felt was manufactured from sacks, some of which had been used to store castor beans. The sera with raised IgE to the felt also had raised IgE to the castor bean extract. By means of RAST inhibition we confirmed that castor bean allergens in the felt were solely responsible for the raised IgE in the sera. The in-vitro RAST results were found to correlate well with the in-vivo prick tests and clinical symptoms.

Diagnosis of hypersensitivity states and the detection of the causative agent has in the past necessitated a close scrutiny of the clinical history together with certain in-vivo test procedures. These procedures include skin or prick test ${ }^{1}$ and provocation testing. ${ }^{2} \mathrm{~A}$ more recent procedure is that of the radio-allergosorbent-test $^{3}$ (RAST). This in-vitro test measures allergen-specific IgE, and has been widely used in the diagnosis of allergy to common environmental agents, ${ }^{4}$ and more recently to occupational allergens. Specific IgE has been reported in workers sensitised to such diverse agents as platinum salts, ${ }^{5}$ flour, ${ }^{6}$ trimellitic anhydride, ${ }^{7}$ and proteases. ${ }^{8}$

We describe the use of RAST to identify an allergen in cases of occupational allergy among workers in an upholstery factory who were unaware of the causative agent. These workers were in contact with materials such as glue, silicone spray, upholstery fabrics, and felt. The results obtained with RAST are compared to prick tests performed in the workers and to their clinical symptoms.

\section{Subjects}

Ten of the 56 operatives employed in the upholstery department of a furniture factory complained of persistent symptoms that led the management to call in the employment medical adviser. Their symptoms,

Received 12 June 1980

Accepted 3 November 1980 which appeared to be job related, are summarised in the table. Although these symptoms had not caused serious disability or loss of working time, they were distressing. Their nature and occurrence more or less simultaneously, about 12 months previously, in a group of people working in the same department, suggested the possibility of an allergy related to exposure to material handled on the job.

\section{RAST assays}

Materials suspected of being allergenic were extracted with phosphate buffered saline (pbs) for $18 \mathrm{hr}$ at $4{ }^{\circ} \mathrm{C}$, centrifuged to remove insoluble material, and then dialysed against pbs. Allergen discs were prepared by coupling an aliquot of the extract to cyanogen bromide activated paper discs as described by Ceska et $a .^{9}$ The concentration of allergen specific IgE in serum was determined by incubating an allergen disc with $200 \mu$ l of a tenfold dilution of serum, and detecting bound IgE with ${ }^{125}$ I-labelled rabbit antihuman IgE (Pharmacia, Uppsala, Sweden). After removal of unbound ${ }^{125} I$, the ${ }^{125}$ I bound to the disc was measured with an LKB Rackgamma II $\gamma$ counter. The RAST score for an allergen was expressed as:

cpm bound to disc incubated with test serum cpm bound to disc incubated with known negative serum 
Clinical symptoms, specific IgE levels, and prick test results to the felt and castor bean extracts

\begin{tabular}{|c|c|c|c|c|c|c|}
\hline \multirow[t]{2}{*}{ Subject } & \multirow[t]{2}{*}{ Symptoms } & \multicolumn{3}{|l|}{ IgE scores } & \multicolumn{2}{|c|}{ Prick test results } \\
\hline & & $\begin{array}{l}\text { Freshly } \\
\text { manufactured } \\
\text { felt }\end{array}$ & $\begin{array}{l}\text { Felt from } \\
\text { furniture } \\
\text { factory }\end{array}$ & $\begin{array}{l}\text { Castor } \\
\text { bean }\end{array}$ & $\begin{array}{l}15 \% \text { felt } \\
\text { extract }\end{array}$ & $\begin{array}{l}0.02 \% \text { castor } \\
\text { bean extract }\end{array}$ \\
\hline A & Coughing, sneezing, tight chest at night, sore eyes & $5 \cdot 0$ & 25 & 17 & 21 & 17 \\
\hline B & Running nose, wheezy chest and cough, sore eyes & $1 \cdot 3$ & 12 & 9 & 20 & 32 \\
\hline C & Tightness of chest, especially on Monday, history of rash & NT & NT & NT & 16 & 19 \\
\hline D & Conjunctivitis with oedema of lids observed & $1 \cdot 5$ & 5 & 7 & NT & NT \\
\hline E & Tightness of chest and cough & $1 \cdot 0$ & $1 \cdot 0$ & $1 \cdot 0$ & -ve & -ve \\
\hline $\mathbf{F}$ & Sore eyes, tightness of chest, and cough & $4 \cdot 7$ & 27 & 15 & 21 & 25 \\
\hline G & Running nose, sore eyes & $1 \cdot 0$ & $1 \cdot 7$ & $1 \cdot 2$ & $-v e$ & -ve \\
\hline $\mathbf{H}$ & Sore eyes & $1 \cdot 2$ & $1 \cdot 3$ & 0.9 & -ve & -ve \\
\hline I & Running nose, sore eyes, tight chest & $1 \cdot 1$ & $2 \cdot 0$ & $2 \cdot 7$ & -ve & -ve \\
\hline J & Sore eyes, sneezing & $1 \cdot 0$ & 0.9 & NT & 8 & 6 \\
\hline
\end{tabular}

A score of two or greater had been found previously (authors' unpublished observations) to be greater than three standard deviations above the mean control serum count and was therefore taken as indicating the presence of allergen-specific IgE. The negative serum used was a pool from three nonatopic members of our laboratory staff. In the RAST assays this serum pool gave a non-specific binding to the allergen discs of about $10 \%$ of the total counts used.

RAST inhibition was performed by a method adapted from that of Yman et al. ${ }^{10}$ Aliquots of a dilution of a serum with a RAST score to the allergen under test were mixed with increasing amounts of soluble phase allergen, then a solid phase allergen disc was added and the IgE bound to the disc determined in the same way as for the RAST scores. In these experiments the results were expressed as a percentage of the counts bound to a disc incubated with serum in the absence of added soluble allergen.

\section{Prick tests}

Solutions for in-vivo prick testing were prepared in sterile Coca's solution containing $50 \%$ glycerol and the prick tests performed as described by Pepys et al. ${ }^{11}$

\section{Results}

The chemical composition of the glue and silicone spray suggested that they were unlikely to cause allergic disease, and the felt seemed the most likely causative agent. Thus $3 \% \mathrm{w} / \mathrm{v}$ extracts were prepared from felt obtained from the furniture factory and from freshly manufactured felt. These extracts were dialysed against $0.02 \mathrm{M}$ ammonium bicarbonate, lyophilised, and reconstituted in pbs to a final concentration of $30 \%$. An aliquot of the concentrated extract was coupled to cyanogen bromide activated paper discs. Sera from four of the ten affected subjects ( $\mathrm{A}, \mathrm{B}, \mathrm{D}$, and $\mathrm{F}$ ) had significant IgE scores to the felt from the furniture factory (table). When these sera were tested against freshly manufactured felt only the two with the highest RAST scores reacted but in a very much less positive manner. This difference in response between the two batches of felt suggested that the allergy might be due either to contamination during storage at the furniture factory, or to variable constituents used in the manufacture of the felt. The felt materials were examined for the presence of storage mites, bacteria, and fungi. No differences were noted in the bacterial or fungal content of the two felt samples, but four species of storage mites were identified in the felt from the furniture factory. RAST assays and prick tests to extracts prepared from mite cultures were found to be negative.

The felt manufacturers reported that the felt was prepared from jute from hessian sacks, with an admixture of sisal and synthetic fibres from carpet waste. In addition, they mentioned that some of the sacks used had previously contained castor beans. A $20 \% \mathrm{w} / \mathrm{v}$ castor bean extract was prepared from ground castor beans, coupled to paper discs, and used in the RAST assay. The RAST scores obtained with this extract paralleled those obtained with the felt extract (table), suggesting an allergen in castor bean. The in-vivo prick tests with the felt and castor bean extracts confirmed the results obtained by RAST (table). Although these results strongly suggested that the allergen in the felt was derived from castor bean, it was possible that the felt also contained other allergenic components. To investigate this possibility RAST inhibition experiments were performed. Figure 1 shows the inhibition of binding to the felt allergen disc with various volumes of the felt extract and the castor bean extract. It is noticeable that $0 \cdot 1 \mu \mathrm{l}$ of the castor bean extract gave the same amount of inhibition as $30 \mu \mathrm{l}$ of the felt extract, showing that the castor bean extract is more allergenic in the RAST assay than the felt extract. In 


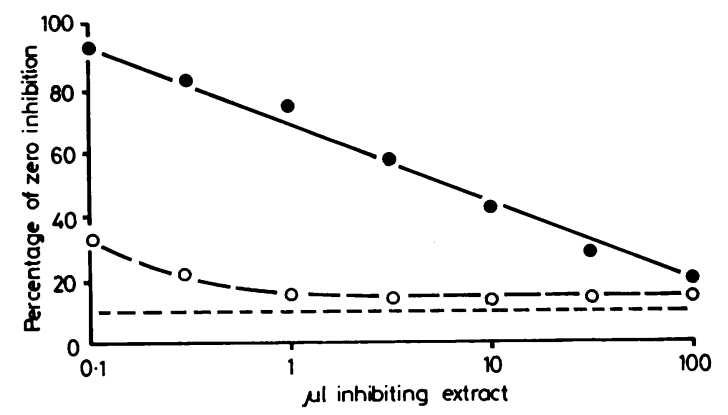

Fig 1 RAST inhibition of felt allergen discs by felt extract and castor bean extract $\bigcirc-0 .---$ represents non-specific binding to the disc by a negative serum.

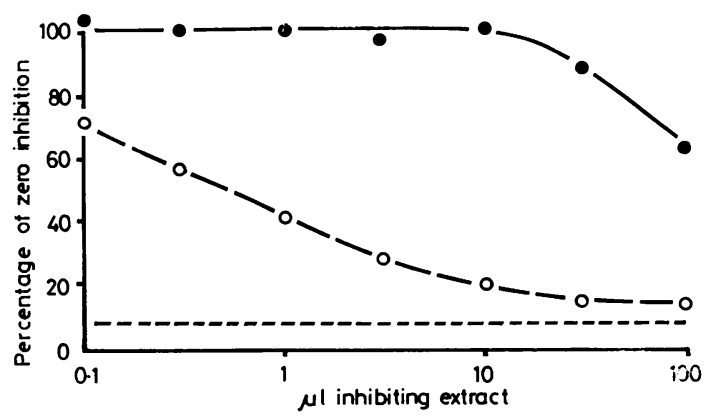

Fig 2 RAST inhibition of castor bean allergen discs by felt extract - , and castor bean extract $\bigcirc-0 .---$ represents non-specific binding to the disc by a negative serum.

addition, $3 \mu$ l of castor bean extract completely inhibited the binding to the felt allergen disc, showing that there is complete cross-reactivity between the allergen in the felt extract and the castor bean allergen. Figure 2 shows the inhibition of binding to the castor bean allergen disc with various volumes of the felt and castor bean extracts. In this case a large amount of felt extract is needed to obtain a relatively small amount of inhibition of binding to the castor bean discs, whereas the castor bean extract totally inhibited this binding, confirming the relative potency of the two extracts.

\section{Discussion}

Allergy to castor bean has not been previously reported among the British population. Castor bean is known to be a potent allergen, however, and allergy to it was first described over 50 years ago. ${ }^{12}$ More recently castor bean allergy has been reported among workers in the coffee industry, who became sensitised while handling sacks that had previously contained castor beans. ${ }^{13-14}$ Karr et al ${ }^{15}$ reported the presence of specific IgE to both coffee beans and castor beans in sensitised workers, and by the use of RAST inhibition showed that the allergens from the coffee beans and castor beans were immunologically distinct. We found that sensitisation occurred through handling felt made from sacks previously used for storing castor beans. The variability in the allergenicity of the extracts prepared from the different felt samples was due to different amounts of castor bean in the felt samples.

The clinical symptoms given in the table are those described by the workers, with only one subject, D, having symptoms at the time of examination. Despite this, however, those describing the worst symptoms had the highest RAST scores, and it is noticeable that four of the six workers who complained of tightness of chest had either a positive RAST or a positive prick test to the felt extract (table). When the RAST scores were compared with the prick tests, there was correlation in six of the eight subjects. Of the other two, one had a low RAST score and a negative skin test, which may have been because several months elapsed between collecting the serum samples and performing the prick tests, and the other a negative RAST and a weak positive skin test. The latter finding is not uncommon and probably occurs because RAST measures circulating IgE, while prick test measures tissue-bound IgE.

By means of RAST inhibition we could show that castor bean was the only allergen in the felt to which the subjects had developed IgE antibodies. The implication is that the castor bean was the only allergen in the felt to which the subjects had become sensitised. Thus although two other known allergens, storage mites and fungi, were present, they were not concerned in the sensitisation of these workers.

Since the investigation positively identified the causative agent, it was possible to advise on the way to avoid future allergic episodes-by asking the felt manufacturers to take greater care in their choice of constituent raw materials.

This study shows the value of RAST assays and RAST inhibition in the diagnosis of industrial allergy and identification of causative agent. We also suggest that the use of an in-vitro assay may often be preferable to provocation testing, which, while it provides an unequivocal diagnosis, is time consuming, expensive, and can cause considerable inconvenience and discomfort to the subject.

We thank Mr A Cunnington, Ministry of Agriculture Fisheries and Food, Slough Laboratory, for carrying out the identification of the storage mites and for supplying the mite cultures; Kew Gardens, Rich- 
mond, Surrey, for a supply of castor beans; $\mathrm{Mr} \mathbf{P}$ Austwick, Aerobiology Unit, Brompton Hospital, for the mycological analysis; Miss B Sharp, EMAS, Bristol, for performing the prick tests; and $\mathrm{Mr} \mathrm{N}$ Foster, director of the felt manufacturing company for his helpful co-operation at all stages of the investigation.

\section{References}

${ }^{1}$ Blackley CH. Experimental researches on the causes and nature of catarrhus aestivus (hay fever and asthma). London: Bailliere, Tindall, and Cox, 1873.

2 Pepys J, Hutchcroft BJ. Bronchial provocation tests in aetiologic diagnosis and analysis of asthma. Am Rev Respir Dis 1975;112:829-59.

${ }^{3}$ Wide L, Benninch H, Johansson SGO. Diagnosis of allergy by an in vitro test for allergy antibodies. Lancet 1967;ii:1105-7.

${ }^{4}$ Evans R, ed. Advances in diagnosis of allergy: RAST. New York: Stratton Intercontinental Medical Book Corporation, 1975.

${ }^{5}$ Cromwell O, Pepys J, Parish WE, Hughes EG. Specific IgE antibodies to platinum salts in sensitised workers. Clin Allergy 1979;9:109-18.
- Baldo BA, Wrigley CR. IgE antibodies to wheat flour components. Clin Allergy 1978;8:109-24.

' Paterson R, Zeiss CC, Roberts M, Prouzansky JJ. Human antihapten antibodies in TMA inhalation reactions. J Clin Invest 1978;62:971-8.

${ }^{8}$ Pepys J, Wells ID, D'Souza MF, Greenberg M. Clinical and immunological response to enzymes of Bacillus subtilis in factory workers and consumers. Clin Allergy 1973;3:143-60.

${ }^{9}$ Ceska M, Eriksson R, Varga JM. Radioimmunoabsorbent assays of allergens. J Allergy Clin Immunol 1972;49:1-9.

10 Yman L, Ponterius G, Brandt R. RAST-based allergen assay methods. Develop Biol Standard 1975;29:151-65.

${ }^{11}$ Pepys J, Tangen O, Perkins FT, Tate H, Brighton WD. Examination of Cocksfoot pollen (Dactylis glomerata) extracts by skin prick test in man, RAST based allergen assay and protein content. Develop Biol Standard 1975; 29:284-94.

12 Bernton HS. On occupational sensitisation to the castor bean. Am J Med Sci 1923;165:196-202.

${ }^{13}$ Frigley KD, Rawling FFA. Castor bean: an industrial hazard as a contaminant of green coffee dust and used burlap bags. J Allergy 1950;21 :545-53.

14 Bernton HS. On occupational sensitisation: A hazard to the coffee industry. JAMA 1973;223:1146-7.

${ }^{15}$ Karr RM, Lehrer SB, Butcher BT, Salvaggio G. Coffee workers asthma: A clinical appraisal using the radioallergo-sorbent test. J Allergy Clin Immunol 1978;62: 143-8. 